\title{
Perception on Odour Pollution from the Operation of Wastewater Treatment Plant (WTP)
}

\author{
Zaini Sakawi \\ Centre of Social, Environment and Development Sustainability (SEEDS), Faculty of Social Sciences and Humanities \\ Universiti Kebangsaan Malaysia
}

\begin{abstract}
Odour pollution from Wastewater Treatment Plant (WTP) is among the most chronic environmental issues affecting the public. Many reports on odour pollution have been made through various media, printed and electronic. To date Malaysia has no clear guidelines or legal Act for enforcement and actions. This study on olfactory sensory was conducted to identify the intensity and characteristics of odour from a WTP to analyse the perception of sensitive receivers to the WTP operations. About 250 questionnaires were purposively distributed among the sensitive receivers within 200 meter radius of the WTP at Bandar Baru Nilai in Negeri Sembilan. The findings indicated that there existed some odour influences from the WTP on the respondents. These influences were of various intensity according to the respondents`age, duration of stay in the area, duration and frequency of odour occurrence. The findings also indicated that odour pollution was also influenced by the meteorological factors such as wind direction, speed of the wind, temperatures, humidity and rain.
\end{abstract}

Keywords: odour pollution, sensitive receivers, waste treatment plant, quality of life

\section{Introduction}

Odour pollution is one of the elements of air pollution which has been attracting critical attention to the authorities in Malaysia. Odour pollution may be caused by various sources such as waste dumpsites, recycling centres, animal farms, sewage treatment plants, rubber processing factories, oil palms factories and agriculture sectors. Odour pollution is an enviromental issue that has become increasingly chronic especially to the sensitive receivers in the surrounding areas of the primary odour sources (Zarra et al., 2008: Zaini et al., 2011a: Zaini et al., 2011b). Odour issues and WTP have also become synonymous identification among sensitive receivers. Numerous issues of odour pollution and the WTP have been increasingly exposed by the media.

The functions of WTP are to collect and treat domestic waste water produced by commercial, industrial and institutional activities. The sewage produced need to be treated to ensure the effluent are clean before entering waterways network. The need for clean water is vital to ensure sustanability of the environment. Human health and quality of life among the community are better guaranteed if the nation has proper sewerage infrastructure. There are six types of sewage treatment plants available in Malaysia, such as Package/Mechanical Sewage Treatment Plants, Aerated Lagoons (AL), Extended Aeration Systems, Oxidation Ditch, Rotating Biological Contractors (RBC), High Rate Trickling Filter (HRTF) (Indah Water Konsortium, 2013).

Odour pollution from the WTP occured due to the release of complex mixture of chemical odour released through the sewerage originated from the biochemical reaction occuring under anaerobic in both sewerage network and sewage treatment plant (Vincent, 2001 and Zarra et al., 2008). The release consist of organic compound and sulphur compound such as hydrogen sulphide $\left(\mathrm{H}_{2} \mathrm{~S}\right)$, Methyl Mercaptan $\left(\mathrm{CH}_{3} \mathrm{SH}\right)$, dimethyl sulphide $\left(\mathrm{CH}^{3}\right) \quad 2 \mathrm{~S}$ and dimethyl disulphide $\left(\mathrm{CH}^{3}\right)$ 2S2, organic nitrogen and non organic such as ammonia $\left(\mathrm{NH}^{3}\right)$, amina, indole dan vaporizable organic compound such as aromatic, aliphatic dan chlorinated hydrocarbon, fat acid, aldehyde, terpenes and keton (Van Langenhove et al., 1985 and Zarra et al., 2008).

There have been various research on WTP conducted in developed countries on various aspects such as on odour management, odour impacts, odour measurement, odour reduction and others. Among studies on monitoring of odour measurement, one particularly on the $\mathrm{H}_{2} \mathrm{~S}$ gas from the WTP was done by Sivret and Stuetz (2012). Meanwhile, Ozturk et al., (2009) and Zarra et al., (2009) focused on a treatment method using chemical sensor system. Other research on control and management were conducted by Kumar et al. (2010), Giuliania et al. (2012) and Estrada et al. (2011).

There have been limited studies on odour pollution in Malaysia. Several studies have been focussing on perception, concentration and intensity particularly from open landfill operation. Among the studies conducted were by Ahmad Zulfahmi (2010), Zaini et al. (2011a), Lukman Ismail (2012), Zaini (2013), Zaini et al. (2012) and Nor Dianiza (2012). A study on perception of WTP influence on odour pollution was conducted by Siti Naeilah (2011) and Mohd Rozaimi et al. (2014). The limitations of the previous studies thus driven this study to focus on investigating on the influence of a WTP on the intensity of the odour, its duration and frequency of occurence; and its influence on physical environment.

\section{Material and Methods}

The method used to obtain the sensitive receivers perception was through a set of questionnaires. The purposive sampling involved 250 sensitive receivers within 200 metres radius of the WTP. The sensitive receivers were the locals and business people surrounding the WTP. The study area (fig.1) are involved three operational areas of the WTP such as Desa Cempaka (Oxidation Disc), Desa Jasmin (Oxidation Disc) dan Taman Semarak (Oxidation Pond). For the Desa Cempaka respondents, 86 survey quenstionnaires were 


\section{International Journal of Science and Research (IJSR) \\ ISSN (Online): 2319-7064 \\ Index Copernicus Value (2016): 79.57 | Impact Factor (2015): 6.391}

distributed, 64 for Desa Jasmin, and 1000 for Taman Package for Social Science (SPSS).

Semarak. The data were analysed using the Statistics

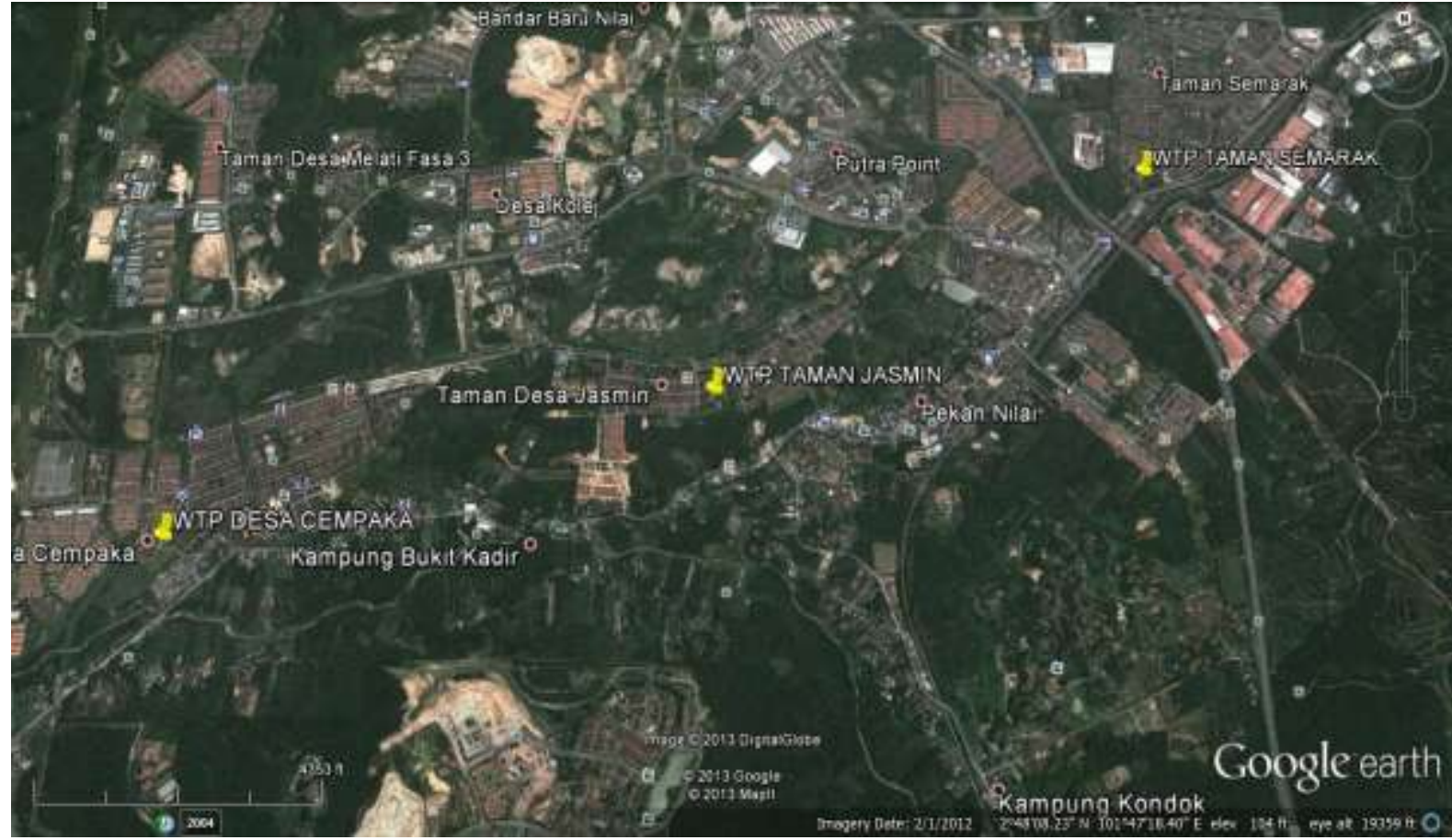

Figure 1: Location of Wastewater Treatment Plant

\section{Results}

\section{Background of the Respondents}

The categories of sensitive receivers involved were appropriate for determining their various perceptions on the intensity, disturbances, effects and odour maagement issues. Table 1 shows the background of the respondents in the study area. Male respondents were $52.8 \%$ and $47.2 \%$ were females. There were three ethnic groups in the area of study, namely the Malays, Chinese and Indians. The Malays were the majority with $52 \%$, Indians $38.4 \%$ and Chinese with $9.6 \%$.
The data show that $10.8 \%$ of the sensitive receivers were 20 year-olds. Minimum age of the sensitive receivers was 15 and there was no maximum age. The majority of respondents aged between 30 to 39 years old was $29 \%$. Those about the age of 40 to 49 were $23.6 \%$ and the remainder $21.2 \%$ were made up of respondents of 50 years old and older. Age factor was also accounted for it may provide significant input on the odour intensity. This significance was evident in a study by Zaini et al. (2012) on the reaction of receivers to various odours in terms of their gender, age and health status. The data also indicated that majority of the sensitive receivers obtained their highest education at secondary school level and only $10 \%$ were university educated (Table 1)

Table 1: Respondents background

\begin{tabular}{|c|c|c|c|c|c|c|c|}
\hline Sex & $\%$ & Age & $\%$ & Length of stay & $\%$ & Education level & $\%$ \\
\hline Man & 52.8 & $<20$ years & 10.8 & $<10$ years & 57.6 & No formal educational & 2.0 \\
Women & 47.2 & $20-29$ years & 21.2 & $10-19$ years & 34.0 & Primary education & 5.2 \\
Total & 100.0 & $30-39$ years & 29.2 & $20-29$ years & 8.0 & Lower secondary certificate & 30.0 \\
& & $40-49$ years & 23.6 & $30-39$ years & 0.4 & Upper secondary certificate & 43.6 \\
& & $50-59$ years & 9.6 & Total & 100.0 & College & 9.2 \\
& & $>60$ years & 5.6 & & & University & 10.0 \\
& & Total & 100.0 & & Total & 100 \\
\hline
\end{tabular}

The Intensity of Odour Generation: The odour intensity was determined on a four-scale categories i.e odourless, less odorous, moderate odour, and strong odour. Fig. 2 shows the intensity of odour indicated by the sensitive receivers. Based on the Table, $15.2 \%$ of the respondents indicated strong odour responses. These indicated that the odour pollution occured due to the close proximity of their houses to the WTP. Whilst, $35.6 \%$ and $13.6 \%$ reported moderate and less odour respectively. The latter were influenced by respondents` houses which were farther and more isolated from the WTP. 


\section{International Journal of Science and Research (IJSR) \\ ISSN (Online): 2319-7064}

Index Copernicus Value (2016): 79.57 | Impact Factor (2015): 6.391

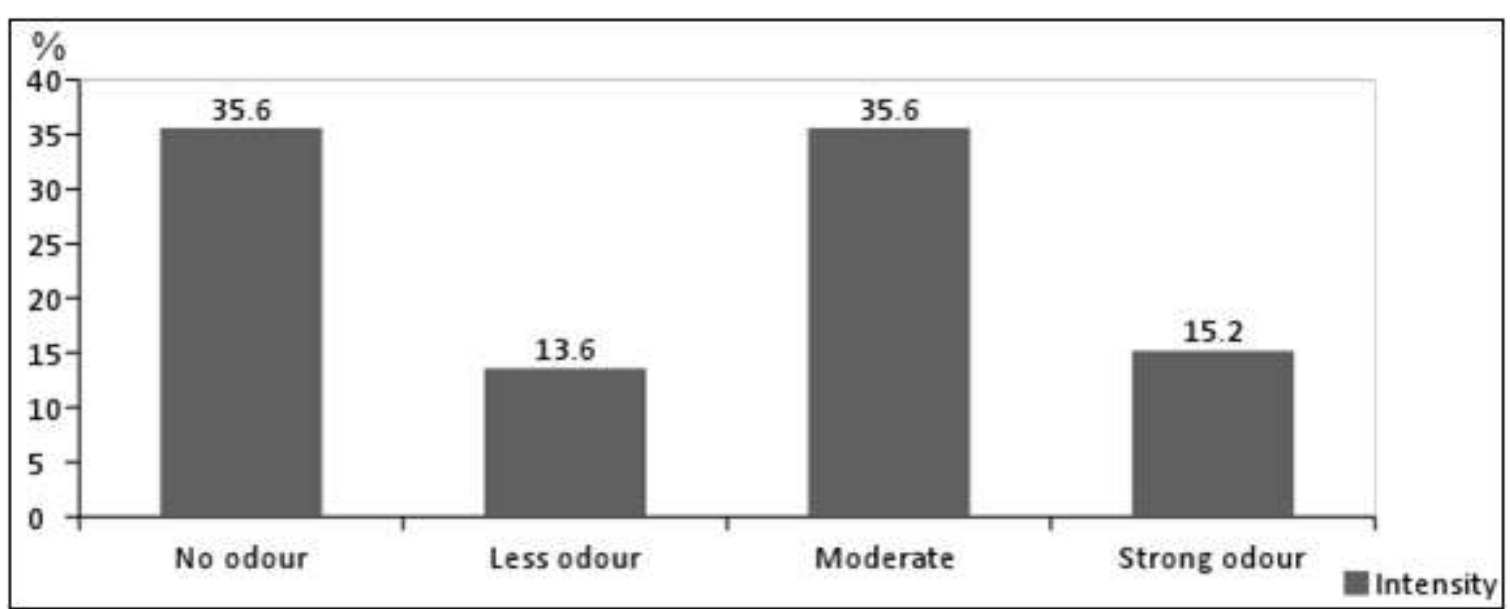

Figure 2: Intensity of odour

Odour Intensity and Gender of Sensitive Receivers: Fig.3 shows the link between odour intensity and gender among the receivers. The findings indicated that the males had more sensitive odour sensory as per the odour intensity scales. For example, moderate intensity responses came from 18.4 males respondents, whilst $17.2 \%$ were those from female respondents. This findings were at variance from that of the
Science of Smell (2004) which indicated that female respondents had stronger sensory reactions compared to males. This study`s results may be attributed to the fact that more male respondents were involved in the survey compared to the females.

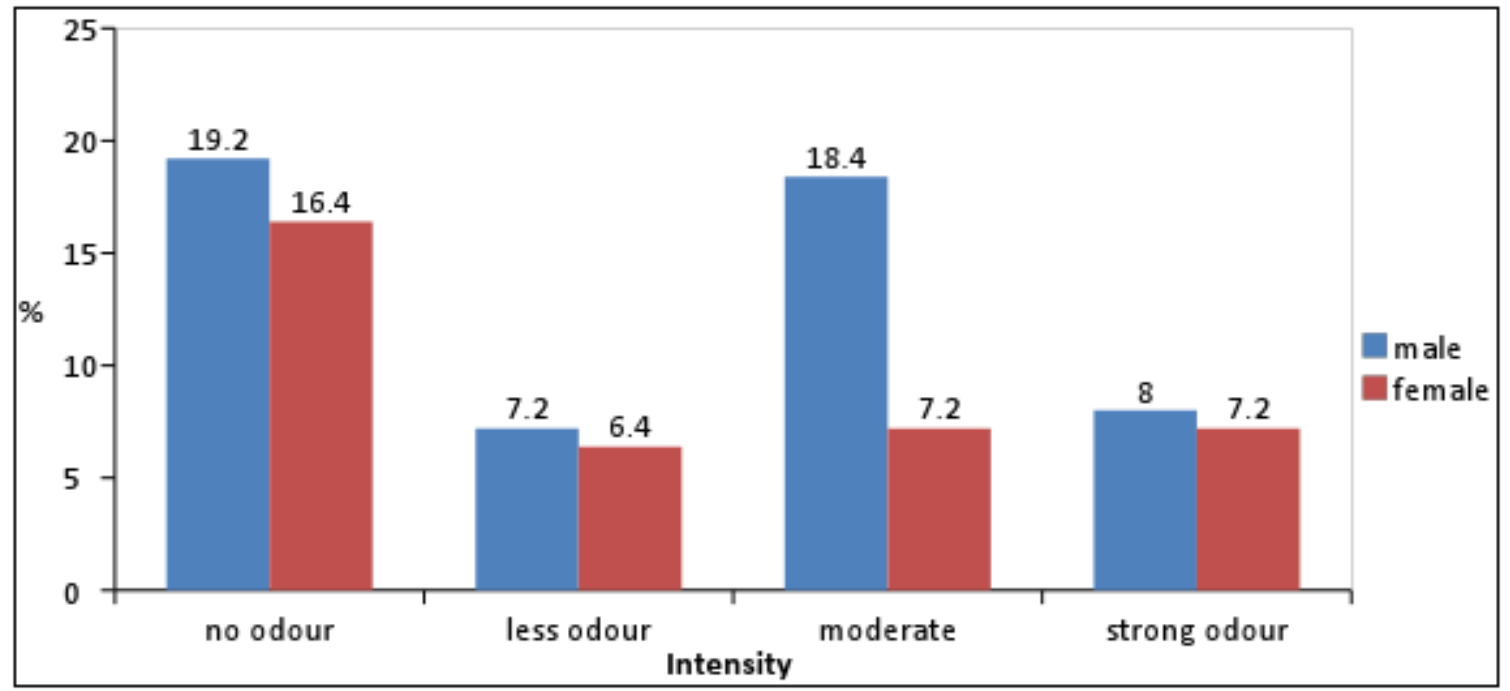

Figure 3: Links between odour intensity and gender of sensitive receivers

Odour Intensity and Duration of Stay among the Sensitive Receivers: Duration of stay of residence is a factor that can influence the respond toward the intensity indicators among individuals. The findings indicated that the duration or period of residence may caused diminishing ability to detect odour intensity. Fig.4 shows the link between the intensity of odour and period of stay among the sensitive receivers. For example, for those indicating higher odour intensity, their period of stay was less than 10 years, much higher than those who have been in the area for more than 20 years. For those staying for 10 years and below, their indication of the odour varies. About $22.4 \%$ indicated no odour, $8 \%$ on less odour, $18.8 \%$ perceived moderate odour and $10 \%$ indicated strong odour. For those staying for 20 to 29 years, $4 \%$ indicated odourless, $3.2 \%$ marked moderate odour, and $1.6 \%$ perceived both less and strong odour. 


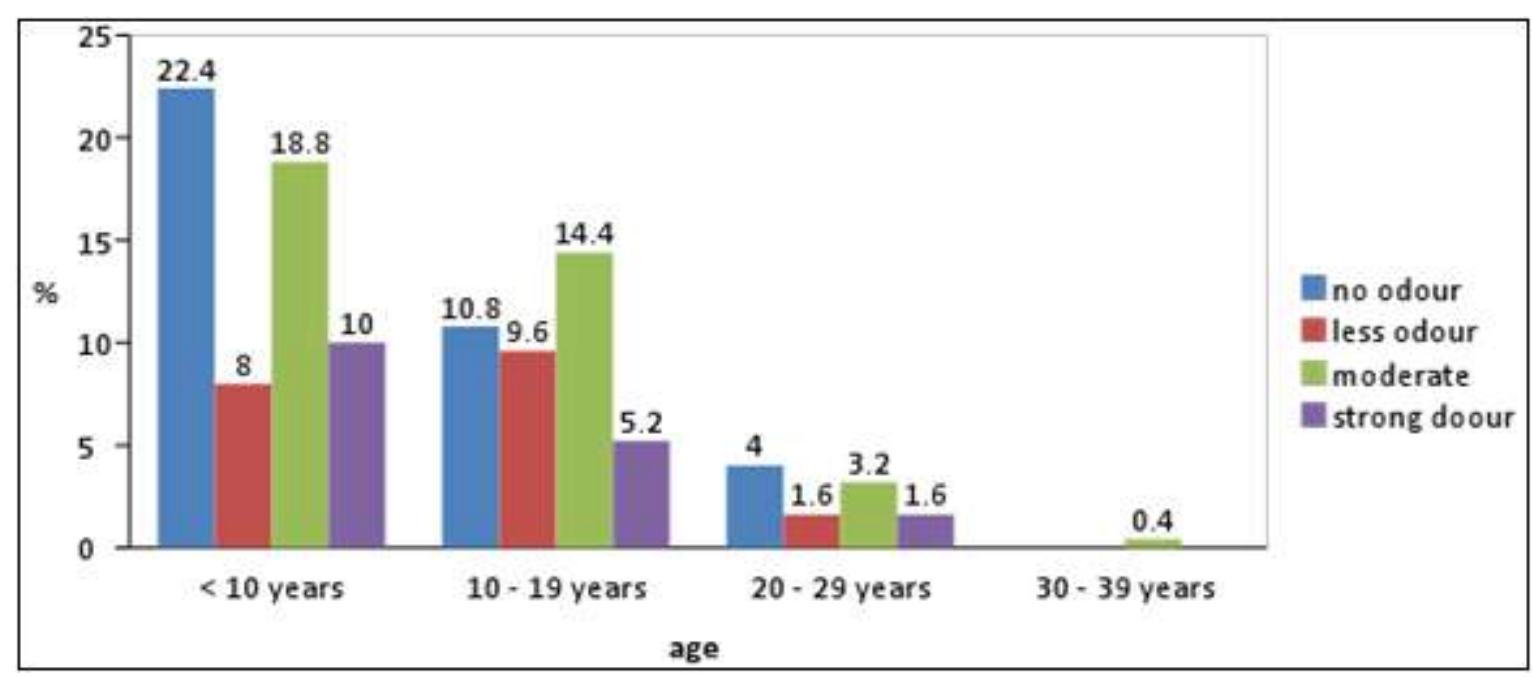

Figure 4: Links between odour intensity and duration of residence of the sensitive receivers

Duration of Odour Occurence: The duration within which the odour linger in the air is a significant characteristics of odour pollution. The duration of odour lingering affect the locals daily activities. Based on Fig.5, the findings indicated that the duration of odour lingering occured for 1 and up to 12 hours a day. About $48.8 \%$ of respondents gave the highest indication of occurence of odour in atmosphere as less than 1 hour. Odour formed during the short period had given less impact to sensitive receivers, provided they take preventive actions. Furthermore, The respondents indicated that the duration of odour in atmosphere for between 1 to 3 hours was at $10.8 \%$. While, the odour lingering for more than 12 hours was only indicated at $3.2 \%$. The odour was not occuring continuosly but varied according the meteorological factors such as weather, wind speed and wind direction.

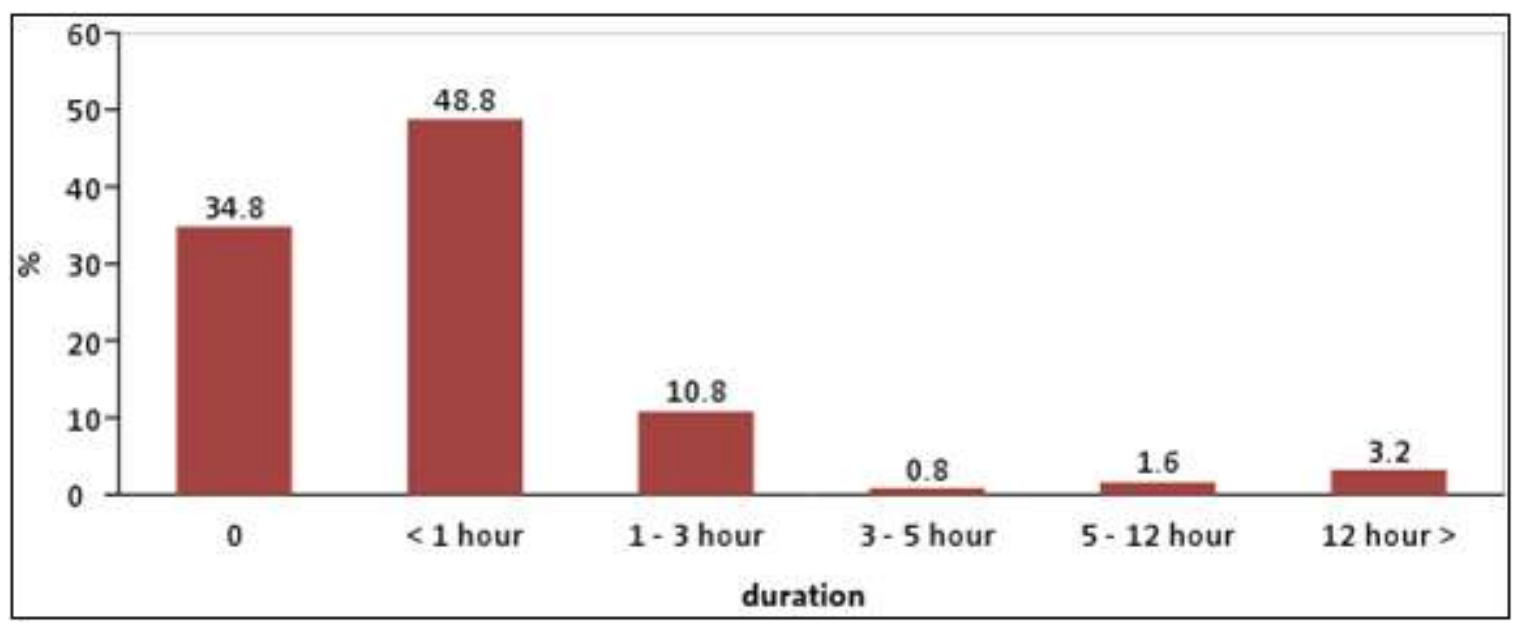

Figure 5: Duration of odour occurence

\section{Frequency of Odour Pollution Disturbance}

Fig. 6 shows the frequency of disturbances of the odour occuring in the area of study. The findings indicated that there were various frequencies of disturbances. Higher perception of disturbances as occuring once a week was at
$32.4 \%$. While, only $4 \%$ of the respondents indicated a daily occurence. This clearly indicated as far as the frequency was concerned, the odour pollution from the WTP was not a major issue for it was detected only once for each week. 
International Journal of Science and Research (IJSR)

ISSN (Online): 2319-7064

Index Copernicus Value (2016): 79.57 | Impact Factor (2015): 6.391

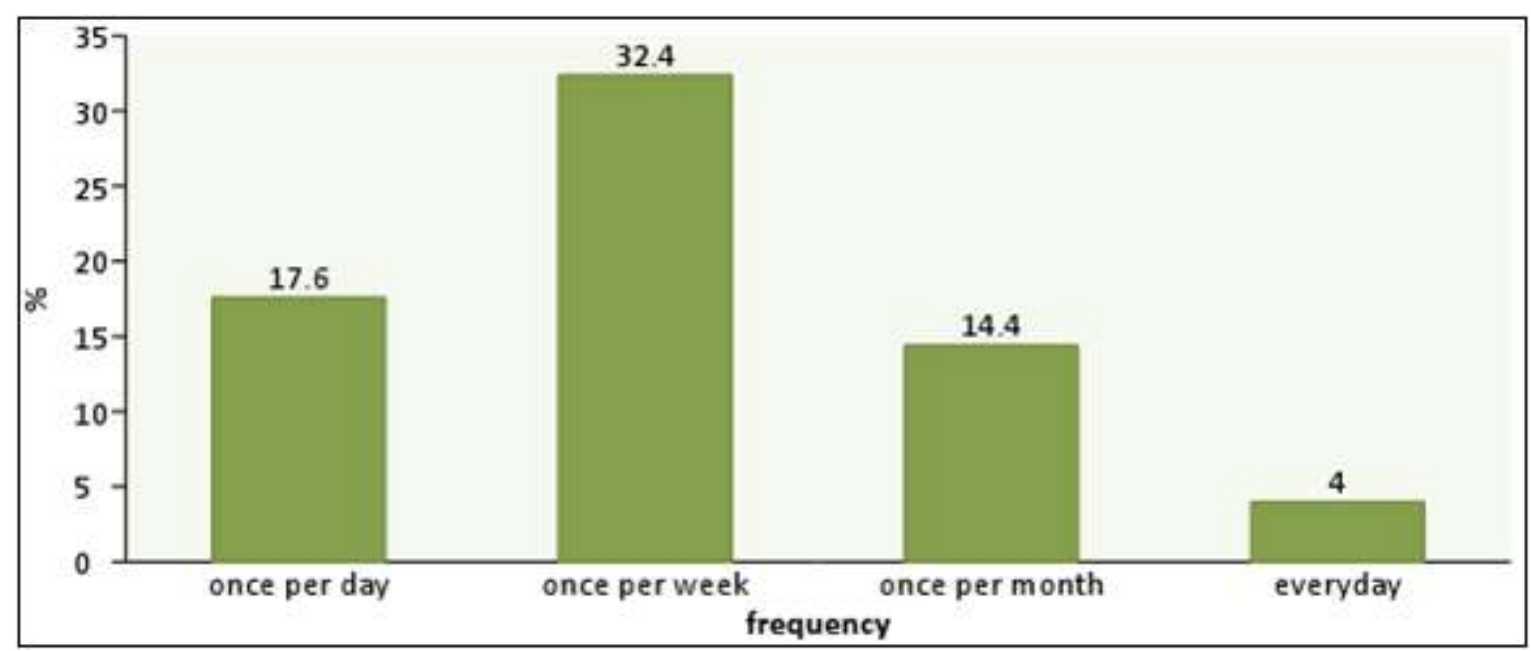

Figure 6: Frequency of odour pollution disturbance

Meteorological Factors Influencing Odour Generation

Odour generation is linked to the meteorological conditions of the locality. Meteorological factor is a major component of the enviroment that can influence the frequency and intensity of the odour detected. Other than that, the direction of wind and its speed, temperatures and humidity also influenced odour concentration and intensity. Fig.7 shows the meteorological influence on the generation of odour based on the perceptions among the sensitive receivers. About $35.6 \%$ of the receivers indicated rain as a major factor influencing the intensity of odour. In addition, wind factor was also found to influence odour intensity (24.4\%). Less than $10 \%$ of respondents indicated odour intensity was affected by the hot and dry weather and other meteorological factors.

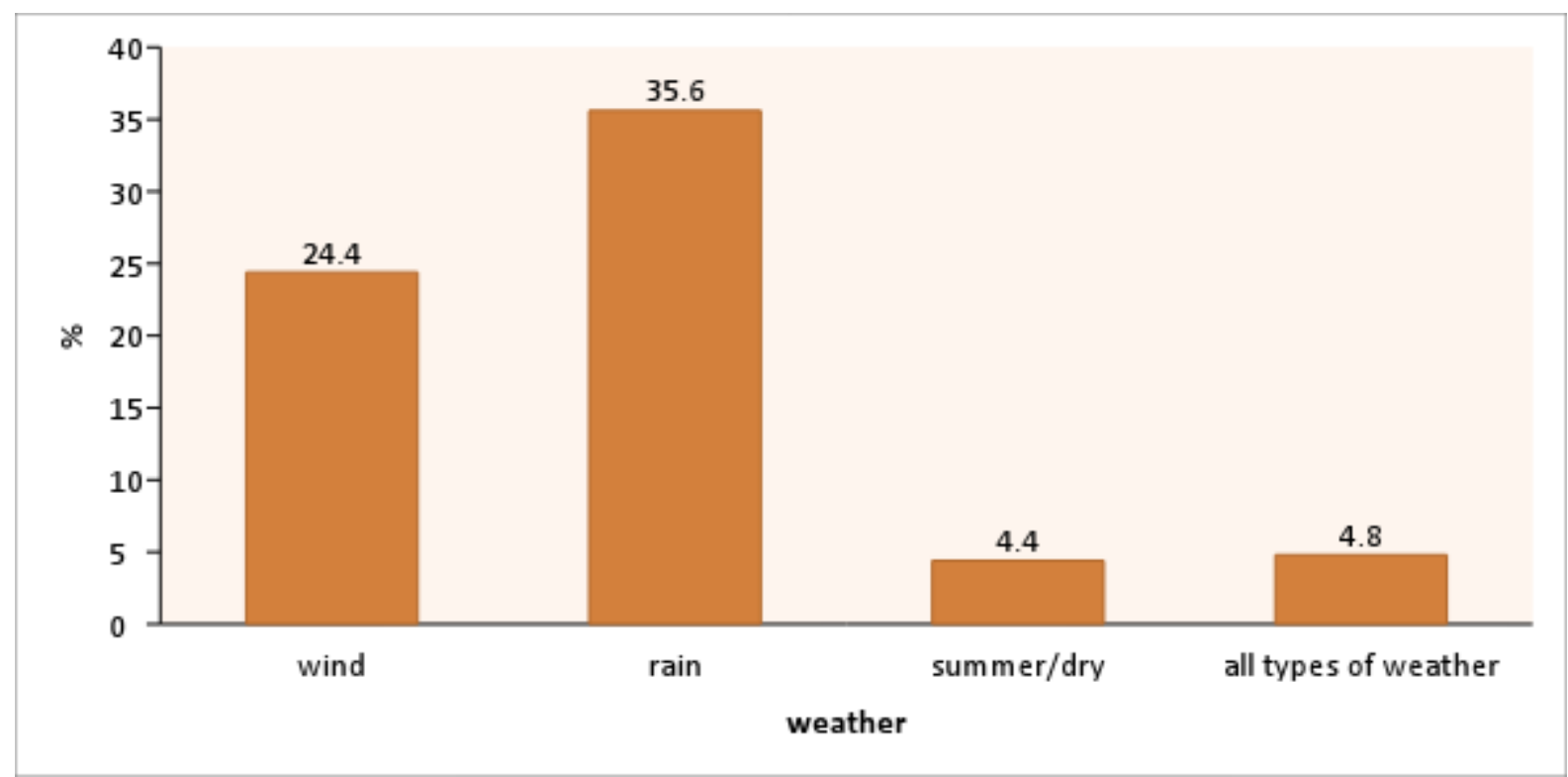

Figure 7: Meteorological factors influencing odour generation

Impact of Odour Pollution on Sensitive Receivers: Odour pollution not only has an impact on the physical environment but also to the human environment. The findings have evidently indicated the impact on human environment particularly human wellbeing and health. Fig. 8 shows that more than $60 \%$ of the respondents indicated the impact of the odour on their lives. The other 53.2\% respondents felt disturbed by the pollution and affected their living peace $(52 \%)$. While $22 \%$ respondents opined that their health were affected due to the WTP odour. 
International Journal of Science and Research (IJSR)

ISSN (Online): 2319-7064

Index Copernicus Value (2016): 79.57 | Impact Factor (2015): 6.391

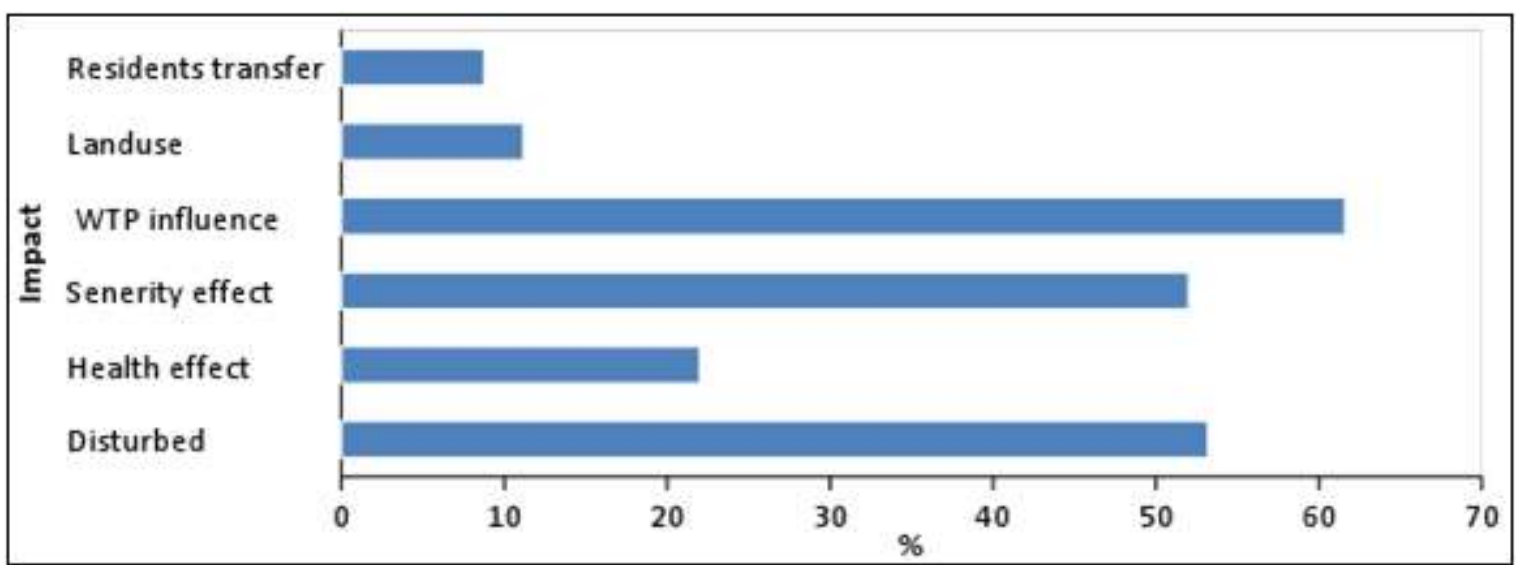

Figure 8: Impact of odour pollution on sensitive receivers

\section{Discussion}

The results indicated that moderate odour intensity scored the highest scale by the sensitive receivers. Moderate odour was perceived by 18.4 males respondents, higher than those indicated by the female receivers at $17.2 \%$. This finding was at variance with those of Science of Smell (2004), for this present study involved more male respondents. For other odour scales, it was also found that there were higher males responses.

The sensitivity of respondents odour sensory was also affected for those who have lived for some time in the area affected with odour pollution. These respondents became immune to foul odour produced in the environment including those from the WTP. The findings also indicated that the respondents living for less than 20 years have more active olfactory sensory for they were more able to detect the odour pollution from the WTP in their area. For those living in the area for more than 20 years, their odour sensitivity was reduced and their capacity for detecting odour diminished.

Regarding the frequency of the odour occurence, it was found to occur on once-a-week basis. Those receiving the weekly odour were those living farther away from the WTP compared to those receiving it on once-in-a day basis. Insulation and mitigating factors by the Indah Water company have also influenced the pattern of the spread of the odour through the farming of buffer plants around the WTP to prevent the odour from reaching the population. The findings also indicated that the odour produced were influenced by the meteorolgical factors. Rainy days were the peak time when the odour was mostly emitted due to lack of air movement.

\section{Conclusion}

Evidently the community`s perception is important for detecting and clarification of issues for preventive actions of the generated odour pollution from WTP. The local communities who have been exposed to the WTP generated odour have produced mostly negative reactions to the issues. The odour issues have been adversely affecting the socioeconomic conditions of the local community. The released of odour from any source not only adversely affected human health but also on the land use. Furthermore, the lifestyle of the local community will change permanently, when they are hampered from doing their outdoor activities; and worse when they have to move to more conducive place to avois the hazards of the odour from the WTP.

\section{Acknowledgement}

The researchers wish to gratefully acknowledgement financial support for this research by Institute of Climate Change and Center of Social, Environment and Development Sustainability (SEEDS), Faculty of Social Sciences and Humanities, Universiti Kebangsaan Malaysia under grant code DPP-2013-145 and GUP-2017-039.

\section{References}

[1] Ahmad Zulfahmi Bin Mohd. 2010. Study on odour pollution from Pajam Open Landfill Nilai, Negeri Sembilan. Latihan Ilmiah. Program Geografi. Universiti Kebangsaan Malaysia.

[2] Estrada JM., Kraakman NJ., Munoz R. And Lebrero R. 2011. A comparative analysis of odour treatment technologies in wastewater treatment plants. Evironmental Science Technology 45(3): 1520-5851.

[3] Giuliani S., Zarra T., Nicolas J., Naddeo V., Belgiorno V. And Romain AC. 2012. An alternative approach of the E-Nose training phase in odour impact assessment. Chemical Engineering Transaction 30(21): 978-88.

[4] Indah water Konsortium . 2013. Planning of sewerage system. Kuala Lumpur: Malaysia.

[5] Kumar. K. S., Kumar, P. S. and Ratnakanth Babu, M. J. 2010. Performance Evaluation Of Waste Water Treatment Plant. International Journal of Engineering Science and Technology 2(12): 7785-7796.

[6] Lukman Ismail. 2012. Study of odour and gases from Fefuse Derived Fuel (RDF) operation. Latihan Ilmiah. Program Geografi. Universiti Kebangsaan Malaysia

[7] Mohd. Rozaimi Ariffin, Zaini Sakawi and Lukman Ismail. 2014. Perception of odour pollution impact from waste treatment plant on health, psychology and physiology of sensitive receivers. Research Journal of Applied Sciences, Engineering and Technology 8(9): 2042-2047.

[8] Nor Dianiza Binti Mohd Hassim. 2013. Impact of odour pollution on psycology and health of sensitive receptor surrounding Wastewater Treatment Plant.

\section{Volume 6 Issue 12, December 2017}




\section{International Journal of Science and Research (IJSR) \\ ISSN (Online): 2319-7064 \\ Index Copernicus Value (2016): 79.57 | Impact Factor (2015): 6.391}

Latihan Ilmiah. Program Geografi. Universiti Kebangsaan Malaysia

[9] Ozturk, Z., Tasaltin, C., Engin, G.O., Gurek, A.G., Atillia, D., Ahsen, V. and Ince, M. 2009. Evaluation of a fast wastewater odour characterisation procedure using a chemical sensor array. Environmental Monitoring Assessment 151(1-4): 369-75.

[10] Science of smell 2004. Science of smell Part 3: Odor detection and measurement (http://www.extension.iastate.edu/airquality).

[11] Siti Naielah Binti Ibrahim @ Yusof. 2011. Community perception on odour pollution from Waste Treatment Plant at Seksyen 7 and Seksyen 15 Bandar Baru Bangi, Selangor. Latihan Ilmiah. Program Geografi. Universiti Kebangsaan Malaysia.

[12] Sivret, E. and Stuetz, R. M. 2012. Sewer odour abatement monitoring: An Australian survey. Water Science \& Technology 66(8): 1716-21.

[13] Van Langenhove, H., Roelstraete, K., Schamp, N. and Houtmeyers, J. 1985. GC-MS identification of odorous volatiles in wastewater. Water Research 19 (5) (1985), pp. 597-603.

[14] Vincent, A. J. 2001. Sources of odours in wastewater treatment. R.M. Stuetz, F.B. Frechen (Eds.), Odours in Wastewater Treatment: Measurement, Modelling and Control, IWA Publishing, London.

[15] Zaini Sakawi, SharifahMastura S.A., Othman Jaafar and Mastura Mahmud. 2011a. An analysis of odour concentration using odour concentration meter XP-329 at landfill vicinity. Research Journal of Applied Sciences 6(5): 324-329.

[16] Zaini Sakawi, SharifahMastura S.A., Othman Jaafar and Mastura Mahmud. 2011b. Community perception of odor pollution from the landfill. Research Journal of Environmental and Earth Sciences 3 (2): 142-145.

[17] Zaini Sakawi, Sharifah Mastura Syed Abdullah, Othman Jaafar, Mastura Mahmud, Lukman Ismail \& Mohd. Rozaimi Ariffin. 2012. Persepsi penerima sensitive ke atas pencemaran bau dari tapak pelupusan secara terbuka. E-Bangi: Journal of Social Sciences and Humanities 7 (1): 284-293.

[18] Zaini Sakawi. 2013. Physical measurement and perception surveys of sensitive receptors of odour pollution from landfill sites. Thesis PhD. Geography Program. Universiti Kebangsaan Malaysia.

[19] Zarra, T., Naddeo, V., Belgiorno, V., Reiser, M. and Kranet, M. 2008. Odour monitoring of small wastewater treatment plant located in sensitive environment. Water Science \& Technology 58 (1): 8994.

[20] Zarra T., Naddeo V., Belgiorno V., Reiser M., Kranert M. 2009. Instrumental characterization of odour: combination of olfactory and analytical methods. Water Science \& Technology 59(8): 1603-9.

Volume 6 Issue 12, December 2017 www.ijsr.net 